\title{
STRATEGI INDONESIA DALAM MEWUJUDKAN POROS MARITIM DUNIA DI TENGAH KEBIJAKAN JALUR SUTRA MARITIM CHINA
}

\author{
Muhammad Zulham ${ }^{1}$, Hendra Maujana Saragih ${ }^{1}$ \\ ${ }^{1}$ Program Studi Hubungan Internasional,Universitas Nasional \\ email : mzulham712@gmail.com, hendramaujana@gmail.com
}

Korespondensi : hendramaujana@gmail.com

\begin{abstract}
Global Maritime Fulcrume Policy initiated by President Joko Widodo became one of the main focuses of national development during the Jokowi - JK presidency. The vision of the Global Maritime Fulcrume is triggered in the direction of Indonesia's national development based on marine activities. The enforcement of the sovereignty of the maritime territory of NKRI, the revitalization of the maritime economic sectors, the strengthening and development of maritime connectivity, the rehabilitation of environmental degradation and the conservation of biodiversity, as well as the enhancement of the quality and quantity of marine human resources are the main programs in the administration of President Jokowi to realize Indonesia as the global maritime fulcrum. Before the policy of the Global Maritime Fulcrume was initiated, in 2013 the Chinese Government under Xi Jinping will re-establish the concept of "The Silk Road" in its foreign policy agenda. Maritime Silk Road which is promoted to become China's new slogan in various international forums become one of the factors that can be utilized for Indonesia or also become one of the obstacle factor to towards the vision of maritime axis of the world considering China is a country that has made unilateral claim of South China Sea area which will surely stand against the stability of the maritime territory of Indonesia. Of course this makes Indonesia take special care in its maritime strategy.
\end{abstract}

Keywords: global maritim ulcrum, maritime silk road, maritime strategy, indonesia's strategy, china's maritime

\begin{abstract}
Abstrak
Kebijakan Poros Maritim Dunia yang dicetuskan oleh Presiden Joko Widodo menjadi salah satu fokus utama dalam pembangunan nasional pada periode kepresidenan Jokowi - JK. Visi Poros Maritim yang dicetuskan tersebut menitik fokuskan kepada pembangunan nasional Indonesia yang berbasiskan dengan aktifitas di laut. Penegakkan kedaulatan wilayah laut NKRI, revitalisasi sektor-sektor ekonomi kelautan, penguatan dan pengembangan konektivitas maritim, rehabilitasi kerusakan lingkungan dan konservasi biodiversity, serta peningkatan kualitas dan kuantitas SDM kelautan merupakan program- program utama dalam pemerintahan Presiden Jokowi guna mewujudkan Indonesia sebagai proros maritim dunia. Sebelum kebijakan Poros Maritim Dunia tersebut dicetuskan, pada tahun 2013 Pemerintah China di bawah Xi Jinping mengumumkan akan menghidupkan kembali konsep "Jalur Sutra" dalam agenda kebijakan luar negerinya. Jalur Sutra Maritim yang kemudian
\end{abstract}


dipromosikan menjadi slogan baru China di berbagai forum internasional menjadi salah satu faktor yang dapat dimanfaatkan bagi Indonesia atau pula menjadi salah satu faktor penghambat untuk menuju visi poros maritim dunia tersebut mengingat China merupakan negara yang telah melakukan klaim sepihak kawasan Laut China Selatan yang tentunya akan berdapak terhadap stabilitas wilayah perbatasan maritim Indonesia. Tentu hal tersebut membuat Indonesia behati- hati dalam strategi maritimnya.

Kata kunci: poros maritim dunia, jalur sutra maritim, strategi maritim, strategi indonesia, maritim china

\section{PENDAHULUAN \\ Latar Belakang Masalah}

Kebijakan Poros Maritim Dunia (PMD) yang dicetuskan oleh Presiden Joko Widodo (Jokowi) menjadi salah satu fokus utama dalam pembangunan nasional pada periode kepresidenan Jokowi - JK. Poros Maritim yang dicetuskan tersebut berfokus kepada pembangunan nasional Indonesia yang berbasiskan dengan aktifitas di laut. Penegakkan kedaulatan wilayah laut Negara Kesatuan Republik Indonesia (NKRI), revitalisasi sektor-sektor ekonomi kelautan, penguatan dan pengembangan konektivitas maritim, rehabilitasi kerusakan lingkungan dan konservasi biodiversity, serta peningkatan kualitas dan kuantitas sumber daya manusia (SDM) kelautan merupakan program- program utama dalam pemerintahan Presiden Jokowi guna mewujudkan Indonesia sebagai proros maritim dunia (http://www.presidenri.go.id/maritim/indonesia-sebagai-poros-maritim-dunia.html diakses pada tanggal 15 Maret 2017)

Indonesia merupakan negara kepulauan dengan jumlah 17.499 pulau dengan luas wilayah laut 93.000 kilometer persegi dengan panjang garis pantai 81 ribu kilometer persegi. Luas perairan itu meliputi perairan kepulauan, laut territorial dan Zona Ekonomi Eksklusif (ZEE) 6.159.032 kilometer persegi. Diapit oleh Samudera Pasifik dan Samudera Hindia serta Benua Asia dan Benua Australia, Indonesia memiliki 39 selat yang memiliki keterkaitan dengan selat lain di kawasan Asia. Indonesia memiliki empat dari sembilan choke point yang ada di dunia. Empat choke point yang dimaksud di sini adalah Selat Malaka, Selat Makassar, Selat Sunda dan Selat Lombok dan keempat selat itu sering dijadikan sebagai jalur pelayaran internasional. Dari itu semua, Indonesia menjadi barometer kawasan dan kunci stabilitas kawasan perairan Indonesia.

Melihat dasar konsep dari pilar- pilar poros maritim tersebut, seharusnya dalam pelaksanaan konsep poros maritim mendahulukan implementasi kedaulatan di laut. Penyelesaian batas-batas laut dan penguatan pertahanan di laut - memastikan efek deterrence (pencegahan) dan pengendalian laut untuk memastikan penggunaan laut untuk kepentingan sendiri (sea control) dan mencegah penggunan laut untuk kepentingan selain NKRI. Jika kedaulatan di laut tercapai dan terjaga, maka akan lebih mudah untuk melaksanakan pilar-pilar lainnya. Indonesia adalah negara yang sangat cinta damai, namun prinsip si vis pacem, para bellum (jika menginginkan perdamaian, maka harus siap perang) perlu diimplementasikan untuk menguatkan kedaulatan laut NKRI. Setelah kedaulatan laut kita terpenuhi dan terjaga, maka 
bolehlah kita menggunakan prinsip si vis pacem, para pactum (jika menginginkan perdamaian, jagalah perdamaian itu).

Sebelum kebijakan Poros Maritim dicetuskan oleh Presiden Joko Widodo, China telah mencetuskan konsep Jalur Sutera Maritim (JSM) oleh Presiden Xi Jinping pada tahun 2013. JSM telah dicanangkan China untuk kerjasama internasional supaya lebih melibatkan semua negara-negara sedang berkembang untuk saling berpartisipasi dalam membangun perekonomiannya. Dan mengimplementasikan pembangunan ekonomi di jalur damai dengan moto "Menerima harmoni dengan keragaman" atau bertoleransi dan harmoni dalam keragaman. Kini kita dapat dikatakan tinggal di era globalisasi, hubungan antara lokasi maupun kawasan di belahan dunia juga telah nyaman dan cepat. (https://www.academia.edu/12313219/ diakses pada tanggal 20 Maret 2017). Seperti diketahui, kegiatan komersial yang sibuk sekarang, transportasi laut telah menyumbang lebih dari dua per tiga dari total pengiriman barang dunia dan sangat penting untuk mengintegrasikan ekonomi dunia. (Indriyana, 2005).

Pasca menjabat sebagai President China, Xi Jinping terus melakukan upaya untuk melakukan ekspansi bagi peranan China pada level state-system (level sistem negara). Salah satu yang diinisiasi oleh Presiden Xi adalah membangun ulang kejayaan Jalur Sutra China. Jalur Sutra sendiri merupakan jalan perdagangan kuno yang dirintis semenjak tahun 206 sebelum masehi, di era Dinasti Han. Dimasa kegemilangannya Jalur Sutra membentang sejauh lebih dari 6000 kilometer menghubungkan China dengan peradaban barat (Ivan, 2007).

Dalam kaitannya dengan kebijakan poros maritim yang dikeluarkan oleh Presiden Jokowi, tentu kebijakan JSM China dapa menjadi batu loncatan untuk mewujudkan Indonesia sebagai PMD. Namun, hal tersebut juga dapat merugikan Indonesia ataupun negara- negara ASEAN yang merupakan organisasi yang dimana Indonesia merupakan anggotanya. Pasalnya dalam konflik di Laut China Selatan, Indonesia merupakan negara yang tidak terjun secara langsung dalam konflik tersebut (Untung, 2016). Hal tersebut membuat Indonesia berada situasi dilema antara menjadikan JSM sebagai batu loncatan untuk mewujudkan Indonesia PMD Atau Indonesia harus berjuang sendiri dalam mewujudkan cita-cita tersebut. Jika Indonesia menjadikan JSM China sebagai batu loncatannya, besar kemungkinan ASEAN akan dilanda perpecahan dan besar kemungkinan Indonesia akan menjadi sasaran berikutnya China dalam sengketa di kawasan Laut China Selatan. Atas dasar ini bagaimanakah upaya Indonesia dalam mewujudkan Poros Maritim Dunia di tengah kebijakan Jalur Sutra Maritim China.

\section{LANDASAN TEORITIK Strategi}

Pada penelitian ini penulis akan menggunakan teori strategi. Strategi adalah sebuah cara yang digunakan dalam rangka mencapai sebuah kemenangan maupun sebuah tujuan. Terdapat berbagai definisi dari para ahli mengenai strategi. Menurut Gregory D. Foster dalam artikelnya yang berjudul A Conceptual Foundation for the Development of Strategy menjelaskan strategi merupakan rencana tindakan yang telah dibentuk dalam rangka meraih sesuatu; tujuan bersama dengan sistem berupa 
langkah-langkah untuk pencapaiannya (Baylis, 2002) yang berarti strategi merupakan keefektifan menggunakan power. Langkah- langkah tersebut dapat menggunakan semua instrumen kekuatan, baik militer maupun non-militer yang terkoordinasi dalam suatu negara atau aliansi untuk mencapai objek yang dimaksud.

Dalam mewujudkan Poros Maritim Dunia-nya, Indonesia melakukan beberapa upaya yang dianggap sangat strategis. Dari dengan adanya peran Tentara Nasional Indonesia Angkatan Laut (https://www.bappenas.go.id, diakses pada tanggal 6 September 2017).

Pembuatan Tol Laut dengan memanfaatkan konektifitas antar pulau di Indonesia sampai pemanfaatan sumber daya alam sektor laut di Indonesia. Tentu langkah- langkah tersebut dilakukan untuk mencapai Poros Maritim Dunia. Selain itu semua, Indonesia melakukan kerjasama dengan China dalam pembangunan infrastruktur guna mempercepat pembangunan tol lautnya demi tercapainya poros maritim dunianya.

\section{Teori Geopolitik}

Berikutnya penulis akan menggunakan geopolitik dari Alfred Thayer Mahan (2004). Mahan mengatakan bahwa "barang siapa yang menguasai lautan, maka ia menguasai dunia". Sehubungan dengan letak geografi suatu negara, dua aspek yang penting untuk dipahami. Pertama, letak suatu negara yang berhadapan dengan banyak lautan dengan komunikasi antara bagian-bagiannya yang berjalan secara baik sehingga musuh sulit untuk menaklukkannya, kedua, letak suatu negara berupa kepulauan yang berada di depan suatu benua atau daratan, sehingga seperti membentengi daratannya. Dalam hal ini, pelabuhan-pelabuhan alam yang dimiliki negara bersangkutan berfungsi serba menguntungkan, baik bagi perdagangan maupun angkatan lautnya. Namun dalam hal ini perlu dicatat bahwa kemudahan daerah pedalaman yang dapat dicapai dari pantai-pantai juga dapat merugikan negara tersebut dalam masa peperangan. Hal ini berkaitanan dengan kebijakan pemerintah, pemanfaatan kepadatan penduduk, dan sikap terhadap negara tetangga. A.T Mahan menggaris-bawahi, bahwa Sea Power atau kekuatan laut merupakan unsur yang sangat penting bagi kejayaan suatu bangsa (Geoffrey, 2004). Sebaliknya bila kekuatan- kekuatan di laut kurang diberdayakan, akan berakibat sangat merugikan negara atau meruntuhkan bangsa tersebut. A.T. Mahan menyatakan, bahwa Kekuatan Laut adalah: "All that tends to make a people great upon the sea or by sea". Contohnya adalah saat kebangkitan kekuatan laut Inggris (British sea power) di masanya. Secara ideal Inggris terletak di persimpangan jalur perdagangan Eropa. Bangsa Inggris mampu memanfaatkan dan mengamankan jalur perdagangannya dari penggunaan laut oleh pihak lawan. Selain daripada itu, posisi geografis Inggris, memberikan proteksi alami dari invasi musuh dan tidak mengharuskan Inggris memiliki kekuatan Angkatan Darat yang besar. (Thayer, 2004).

Dari contoh di atas, dapat diambil pelajaran bahwa keuntungan posisi geografis tidak akan terlihat dominan bila sebuah bangsa tidak memiliki garis pantai yang cukup untuk membangun pelabuhan-pelabuhan, tidak memiliki sumber daya alam yang memadai, dan tidak didukung oleh iklim/cuaca yang baik. Di samping hal 
tersebut cara pandang serta wawasan kelautan dari masyarakat merupakan sumber kekuatan maritim dan kesejahteraan bangsa. Kemampuan pemerintah dalam melaksanakan diplomasi dan mempengaruhi negara lain memiliki peran yang sangat signifikan dalam melakukan dominasi wilayah lautnya. Buku "The Influence of Sea Power Upon History", itu dinilai penting karena buku ini menggambarkan pemikiran Mahan untuk mencapai kekuatan nasional (national power), serta menjelaskan bagaimana cara mengerahkan Sea Power untuk menghadapi musuh. Apa yang dimaksud dengan Sea Power atau Kekuatan Laut, pada dasarnya identik dengan Kekuatan Maritim atau Maritime Power. Apabila kekuatan-kekuatan itu diberdayakan, maka akan meningkatkan Kesejahteraan dan Keamanan Negara. Disamping hal tersebut, Rear Admiral A.T Mahan menyatakan bahwa "keunggulan Angkatan Laut adalah keperluan utama untuk menjadikan negara besar, kuat dan maju". Pelaku operasi pertahanan negara di laut terdiri dari beberapa instansi dengan AL (Angkatan Laut) sebagai inti kekuatan. Kekuatan laut terdiri dari Armada Niaga, Angkatan Laut dan Pangkalan. Selain dari pada itu laut adalah satu kesatuan (The Sea is all One) artinya bahwa laut tidak dapat dipagari, diduduki dan dipertahankan seperti daratan. Sehingga strategi maritim merupakan penguasaan di laut, yaitu dengan menjamin penggunaan laut untuk kepentingan sendiri serta menutup peluang bagi lawan untuk menggunakannya. Pandangan Mahan terhadap dunia secara keseluruhan menekankan diperlukannya kesatuan laut (unity of the sea) sebagai syarat untuk dapat mengawasi dan menguasai lautan dari pangkalan-pangkalan utama di darat. Dikemukakan pula disini perlunya kesatuan pengawasan terhadap pangkalan- pangkalan utama di darat. Dikemukakan pula di sini perlunya kesatuan pengawasan terhadap pangkalan-pangkaln dari darat an ataupun udara sebagai syarat utama untuk dapat menjamin terselenggranya kesatuan pengawasan terhadap lautan. Kekuatan lautan dan strategi angkatan laut menurut penilaina Mahan bergantung pada beberapa phisik-geografis, misalnya kedudukan insular atau kontomental sesuatu bangsa dan politik nasional yang besangkutan dengan masalah angkutan laut, pelayaran niaga dan pangkalan-pangkalan di luar wilayah.

\section{Makna Penting Jalur Sutra Maritim Bagi Indonesia Dan China}

Pada prospeknya, rencana JSM beririsan dengan Doktrin PMD, dimana rencana pembangunan dari masing-masing ide cenderung bersifat integral dan komplementer. Dengan kata lain, baik JSM dan PMD tidak bertolak belakang, melainkan dapat saling bekerjasama, khususnya terkait masalah penyediaan dana bagi pembangunan infrastruktur. Dalam hal ini, Indonesia pun sangat terbuka atas saluran-saluran dana dari luar negeri, baik dalam bentuk share budget, atau sepenuhnya berasal dari pendanaan Asian Infrastructure Investment Bank (AIIB). Demi mewujudkan visi Poros Maritim Dunia (PMD) Indonesia bergabung kedalam (AIIB) dan mengajukan sebagai salah satu negara pendiri, agar dana yang diperlukan untuk mencapai PMD dapat dicapai dari bantuan China, share budget antar negara pendonor/investor lain, atau seutuhnya dibiayai dari kucuran dana AIIB. (http://www.thejakartapost.com/news/2014/12/13/ diakses pada 1 Januari 2018). Apabila rencana ini berjalan sebagaimana skenario diatas - dengan AIIB sebagai salah satu sumber dana pembangunan - maka dapat dikatakan bahwa 
doktrin PMD oleh Indonesia menjadi bagian yang tidak terpisahkan dari JSM China. Konsep jalur tol maritim Indonesia dapat dikembangkan kedalam proyek tol super maritim JSM.

Menurut Luhulima, secara politik, Indonesia harus mengadaptasi materialisasi JSM China dengan bersikeras pembentukan AIIB di Jakarta. Meski Jin Liqun kini tetap menjadi sekretaris jendral AIIB yang dipilih pada 24 Oktober 2014 di Beijing, namun Indonesia harus terus bersikeras untuk menempatkan beberapa fungsi eksekutif dalam AIIB untuk mengimbangi vital interest Indonesia terhadap pertumbuhan JSM. Tidak hanya itu, Indonesia juga kemudian harus meningkatkan sistem pertahanan maritimnya dengan teknologi terbaru untuk mengamankan laut dan jalur komunikasi lautnya, serta terus mengawasi arus lalu lintas di teritorial lautnya.

Baik Indonesia maupun China memiliki strategi dan kepentingan masingmasing dalam wacana JSM dan PMD. Sebagaimana telah dipaparkan, kepentingan ekonomi, politik, keamanan, dan sosial budaya China sangat besar akan realisasi JSM. Perencanaan strategi pembangunan dan arah realisasi JSM juga cenderung sudah lebih jelas dibandingkan PMD oleh Indonesia. Oleh sebab itu, hal yang perlu ditinjau lebih lanjut adalah apakah China atau Indonesia mampu menyelaraskan ideide dan kepentingannya agar dapat sejalan satu sama lain dan sejalan dengan kepentingan negara lain yang terlibat di kawasan.

Menyoroti jika pemanfaatan JSM China oleh Indonesia terjadi, analis Pertahanan Universitas Indonesia (UI) Dr. Connie Rahakundini Bakrie menilai langkah tersebut tidak seharusnya dilihat sebagai suatu ancaman. Karena hal tersebut dapat mendorong Indonesia membangun kekuatan maritim yang mandiri karena secara geografis, Indonesia sangat strategis sebagai poros atau sumbu jalur pelayaran dan perdagangan dunia. Bagaimana posisi strategis tersebut dapat dimanfaatkan China atau negara laut lainnya, maka Pekerjaan Rumah (PR) Indonesia adalah bagaimana Indonesia dapat serta merta memperoleh manfaat sebesar-besarnya, didukung oleh kemampuan yang harus dibangun dan peluang yang ada. Mengingat negara maritim adalah negara yang mampu memanfaatkan dan mengelola laut baik ruangnya maupun kekayaan alamnya serta letaknya yang strategis dengan kemampuan teknologi, ilmu pengetahuan, dan peralatan yang dimilikinya, maka Connie mengacu pada Alfred Thayer Mahan yang mengatakan :

"If a country be imagined having a long seaboard, but entirely without a harbor, such a country can have no sea trade of its own, no shipping, no navy...... Numerous and deep harbors are a source of strength and wealth." (Mahan, 2004).

\section{Potensi Keuntungan JSM}

Prakarsa Jalur Sutra Maritim (JSM) dipresentasikan pada titik penting perkembangan ekonomi Indonesia. Beberapa tahun sebelumnya Indonesia meluncurkan sebuah rencana induk untuk pengembangan ekonomi jangka panjang, yang dikenal sebagai Masterplan Percepatan dan Perluasan Ekonomi Indonesia (MP3EI). MP3EI adalah rencana ambisius, yang bertujuan mendorong Indonesia 
masuk dalam sepuluh besar ekonomi pada tahun 2025. Rencananya memiliki tiga pilar: pengembangan koridor ekonomi atau pusat pertumbuhan, memperkuat konektivitas dan, pengembangan sumber daya manusia dan, sains dan teknologi nasional.

Seperti JSM, PMD masih harus dijabarkan lebih jauh. Kendati demikian, dari sisi apa yang telah dikatakan selama ini, antara lain, pembangunan tol laut dan mungkin juga ekonomi berbasis maritim pada umumnya. Pembangunan tol laut diharapkan bisa mencakup pengembangan pelabuhan di berbagai wilayah di Indonesia serta memperluas dan memodernisasi industri pelayaran negara. Sementara itu, ekonomi berbasis kelautan juga mencakup, di antara komponen lainnya, pengembangan kapal / kapal, infrastruktur dan layanan perbaikan dan pemeliharaan, penangkapan ikan, eksplorasi dan ekstraksi minyak lepas pantai, ekstraksi sumber daya dan pemanfaatan, wisata bahari dan kegiatan rekreasi, pengelolaan lingkungan laut.

PMD pada dasarnya adalah 'penemuan kembali' identitas Indonesia sebagai negara maritim. Sudah lama Indonesia dikelola seolah-olah merupakan negara kontinental yang tidak. Indonesia terdiri dari sekitar 17000 pulau, antara tahun 2000 dan 4000 di antaranya dihuni. Selain itu, sekitar duapertiga wilayah negara tersebut adalah air.

Ada sejumlah alasan yang mungkin untuk tidak mengabaikan terhadap sifat maritim di negara ini. Pertama, populasi Indonesia terkonsentrasi di beberapa pulau besar. Menurut sensus 2010, dari 237 juta orang Indonesia di tahun 2010 sekitar 57,5 persen tinggal di Jawa, 21,3 persen di Sumatera, 7,3 persen di Sulawesi dan 5,8 persen $\quad$ di Kalimantan (Damuri, dalam https://www.csis.or.id/uploaded_file/publications/a_maritime_silk_road_and_indone sia_s_perspective_of_maritime_state.pdf diakses pada tanggal 5 Januari 2018).

Hal tersebut menyebabkan distribusi perekonomian tidak merata karena hanya bertumpu kepada 4 wilayah tersebut. Kedua, investasi infrastruktur kelautan seperti pelabuhan dan transportasi laut mahal. Masalah ini diperburuk lebih lanjut oleh dua faktor. Yang pertama adalah distribusi populasi yang tidak merata dan konsentrasi pembangunan ekonomi di beberapa pulau yang dibahas di atas. Akibatnya, kapal-kapal yang mengangkut barang dari Jawa mengatakan, Jawa ke bagian timur negara itu hampir kosong dalam perjalanan pulang mereka. Inilah salah satu alasan mengapa biaya logistik sangat tinggi di Indonesia, diperkirakan sekitar seperempat dari produk domestik bruto negara tersebut.Faktor kedua, sampai saat ini PT Pelabuhan Indonesia (PT Pelindo) memiliki monopoli atas pengembangan dan pengelolaan pelabuhan negara. PT Pelindo mungkin pada kenyataannya telah mengelola pelabuhan negara tersebut dengan cara yang tidak efisien. Kebijakan cabotage sering disebut-sebut sebagai faktor lain untuk biaya logistik yang tinggi. menunjukkan biaya logistik memang telah meningkat sejak diperkenalkannya kebijakan tersebut dan bahwa kebijakan kobatatan tersebut memiliki bantalan langsung pada kenaikan.

Secara umum, ada tiga pandangan tentang inisiatif JSM. Pandangan pertama berpendapat bahwa JSM adalah 'berkat yang menyamar', karena prakarsa tersebut dapat sesuai dengan visi PMD yang diluncurkan Presiden Joko Widodo di awal 
masa kepresidenannya. Dalam konteks regional, karena JSM mempromosikan konektivitas lebih lanjut antar negara melalui lima tautannya (kebijakan, jalan, perdagangan, mata uang, dan orang-orang). Menurut seorang ilmuwan, JSM dan PMD akan membahas konektivitas, keamanan, dan diplomasi. Oleh karena itu, ada potensi untuk inisiatif JSM ini untuk mengubah perselisihan berkepanjangan mengenai kedaulatan teritorial, khususnya di Laut Cina Selatan dengan menggunakan kegiatan bersama yang konstruktif yang akan memfasilitasi navigasi laut yang mulus di daerah tersebut.

Selain itu, dimasukkannya inisiatif baru seperti JSM atau menjadi salah satu anggota pendiri Asian Inrastucture Investmen Bank (AIIB) dipandang tidak membatasi independensi kebijakan luar negeri Indonesia. Misalnya, dengan keikutsertaannya di AIIB, Indonesia dapat mempertahankan partisipasinya di lembaga keuangan internasional yang ada, seperti Bank Dunia dan Bank Pembangunan Asia. Sebenarnya, dengan berpartisipasi dalam inisiatif baru, Indonesia akan memiliki lebih banyak alternatif untuk melayani kepentingan nasionalnya. Bila dibandingkan dengan inisiatif sebelumnya ( JSM ) adalah proposal pertama yang secara jelas memasukkan Indonesia ke dalam perkembangannya.

\section{Potensi Ancaman}

Beberapa ilmuwan merekomendasikan untuk tidak terburu-buru menerima konsep tersebut, apalagi menyinkronkan PMD dengan JSM, mengingat kondisi yang dibahas di atas. Seperti yang dijelaskan oleh satu pejabat, kesepakatan Indonesia untuk bergabung dengan JSM harus disampaikan dengan hati-hati dengan cara yang tidak akan dianggap sebagai pengakuan diam-diam terhadap tuntutan sembilan jalur yang diterapkan oleh China.

Akhirnya, kelompok ilmuwan tersebut mengambil sikap yang lebih kuat dalam melawan inisiatif JSM. Meskipun mereka tidak secara blak-blakan menyarankan agar pemerintah Indonesia menolak proposal JSM, para ilmuwan atau pejabat di dalam kelompok ini jelas memerlukan penjabaran yang lebih baik dan lebih komprehensif mengenai motivasi di balik inisiatif tersebut, dan bagaimana cara pemerintah China merencanakan untuk menerapkan JSM pada kenyataannya. Mereka meneliti, khususnya, mencoba menggunakan JSM untuk menanamkan kembali Silk Road kuno, karena mereka mencatat bahwa praktik tersebut dirancang seputar hubungan anak-anak di antara pusat / atasan dengan negara-negara pinggiran/inferior.

Ada kekhawatiran bahwa JSM ini akan digunakan sebagai instrumen untuk membagi negara menjadi kelompok orang-orang yang menguntungkan (sejak mereka bergabung dengan JSM) dan sekelompok orang yang tidak menguntungkan (karena mereka tidak bergabung). Mereka lebih jauh khawatir bahwa negara-negara yang berada dalam daftar yang menguntungkan harus membayar konsesi tertentu ke China, seperti memberikan akses ke pasar lokal yang mungkin tidak menguntungkan bagi mereka. Indonesia belum memiliki kemampuan yang cukup untuk mengeksplorasi sumber dayanya sendiri, terutama di laut. Implementasi JSM dikhawatirkan memberi terlalu banyak konsesi dan kesempatan untuk mengeksplorasi ZEE di Indonesia, karena China memiliki teknologi maritim yang 
jauh lebih baik dan Indonesia tidak siap dengan instrumen hukum untuk melindungi dirinya dari praktik eksploitasi.

Para pemangku kepentingan juga melihat paralel antara konsep JSM dan konsep mutiara, dimana JSM akan menjadi bagian dari strategi untuk mengamankan rute militer dan komersial China di laut, dan jalur komunikasi lautnya (SLOC) yang giliran ditujukan untuk mengatasi ekspansi India di kawasan ini. Sementara JSM dipahami sejauh sebuah inisiatif yang dirancang untuk mendorong konektivitas, ada kekhawatiran hal itu dapat digunakan sebagai instrumen lain untuk menyerap sumber daya alam Indonesia dengan harga yang menguntungkan bagi orang Cina. Yang lebih mengkhawatirkan lagi, karena China terus berupaya memperluas sumber energinya ke luar negeri, negara-negara tetangga terus mengawasi kekuatan militer China yang sedang berkembang. Ada kekhawatiran yang berkembang bahwa minat yang kuat untuk melindungi keamanan energinya akan mendorong perluasan pengaruh militer China melalui peningkatan kemampuan militernya sebagai instrumen efektif untuk mendukung kegiatan tersebut. (Damuri, dalam https://www.csis.or.id/uploaded_file/publications/a_maritime_silk_road_and_indone sia_s_perspective_of_maritime_state.pdf diakses pada tanggal 5 Januari 2018).

Walaupun Indonesia tidak bertentangan dengan ekspansi angkatan laut China, penting bagi Indonesia untuk melihat konsistensi dalam tindakan China yang sejauh ini memberi kesan bahwa China menjadi kekuatan yang tegas yang seringkali melenturkan otot militernya untuk diterapkan klaim sepihaknya atas laut tertentu yang juga diklaim oleh negara lain. Oleh karena itu, Indonesia mempertanyakan apakah penerapan inisiatif JSM akan sesuai dengan upaya China untuk memperbaiki kerjasama di kawasan ini - dan karena itu bekerja bersamaan dengan tindakan potensial pembentukan Code of Conduct ( $\mathrm{CoC}$ ) di Laut Cina Selatan - dan dengan demikian mencerminkan bahwa kenaikan China adalah damai yang harus menghibur semua aktor di wilayah ini. Indonesia juga harus memeriksa apakah dalam inisiatif JSM ini China bermaksud untuk memperlakukan negara-negara yang diundang sebagai mitra setara atau apakah akan menerapkan kebijakan historis hubungan anak-anak yang mengubah negara seperti Indonesia menjadi negaranegara pinggiran. Jika yang terakhir sedang berlangsung, maka konektivitas yang akan dibangun melalui JSM hanya akan melayani kepentingan China daripada membawa manfaat bersama bagi semua orang. Skenario seperti itu perlu diantisipasi sebelum JSM dapat diterima.

\section{Strategi Indonesia dalam Mewujudkan Poros Maritim}

Konsep tol laut dapat mengatasi persoalan utama transportasi laut berkaitan dengan ketidakseimbangan volume pengangkutan barang antara kawasan barat dan timur Indonesia. Konsep ini dapat menjadi solusi yang efektif dalam mencegah berlayarnya kapal berkapasitas kosong dari satu tempat ke tempat lain dan diharapkan dapat mewujudkan sistem distribusi barang yang efisien serta terintegrasi. Tingginya biaya logistik Indonesia menjadi beban bagi perusahaan penyedia jasa logistik, yang tentunya berimbas pula pada perusahaan manufaktur. Beban biaya transportasi muncul sejak proses memasok bahan baku sampai dengan proses paling hilir dari rantai pasok, yakni pengiriman barang jadi ke konsumen. 
Inefisiensi dan keterbatasan sarana dalam aktivitas pelabuhan menyebabkan banyak biaya tambahan yang harus dikeluarkan (S. Bahagia, Sandee H, Meeuws R).

Saat ini, jumlah pelabuhan utama di Indonesia mencapai 33 unit yang dilengkapi dengan 217 pelabuhan pengumpul dan 990 pelabuhan pengumpan. Rencana kebijakan mengembangkan konektivitas maritime melalui tol laut, deep seaport, logistik, industry perkapalan, dan pariwisata maritim dalam jangka pendek dilakukan dengan cara meningkatkan kapasitas empat pelabuhan utama, yaitu Belawan, Tanjung Priok, Tanjung Perak, dan Makassar. Sedangkan dalam jangka panjang, keseluruhan pelabuhan utama dan pelabuhan pengumpan akan menjadi tulang punggung bagi jaringan pelayaran domestik dan bagian dari jaringan pelayaran internasional untuk distribusi barang.

Pada periode pemerintahan Jokowi dan Jusuf Kalla, direncanakan akan ditingkatkan kapasitas 24 pelabuhan untuk mendukung tol laut yang terdiri dari 5 pelabuhan hub dan 19 pelabuhan feeder. Pelabuhan yang menjadi hub tol laut terdiri dari Pelabuhan Belawan/ Kuala Tanjung, Tanjung Priok, Tanjung Perak, Makassar, dan Bitung. Pelabuhan yang menjadi feeder tol laut terdiri dari Pelabuhan Malahayati, Batam, Jambi, Palembang, Panjang, Teluk Bayur, Tanjung Emas, Pontianak, Banjarmasin, Sampit, Balikpapan/Kariangau, Samarinda/ Palaran, Tenau/Kupang, Pantoloan, Ternate, Kendari, Sorong, Ambon, dan Jayapura (Bappenas, 2014).

Kebijakan konektivitas maritim berupa pembangunan tol laut memiliki fokus dan target. Fokus pada tahun 2014 adalah memenuhi kebutuhan pelayaran perintis, sedangkan target pada tahun kelima adalah mewujudkan system transportasi laut yang mampu menekan biaya logistik menjadi 20 persen dari pendapatan domestik bruto, menumbuhkan armada pelayaran nasional dari 10 menjadi 30 persen, melakukan peremajaan kapal nasional dengan menekan jumlah kapal di atas 25 tahun dari 70 persen menjadi 50 persen, dan mengurangi waktu pelayanan pelabuhan pada pelabuhan utama dari 6 sampai 7 hari menjadi 3 sampai 4 hari (Manfaat, 2015). Target ini sangat mungkin dicapai, apabila sejumlah langkah penting dilakukan, terutama melakukan perencanaan lintas sektoral, serta melibatkan pemerintah daerah dan masyarakat.

Bergabungnya Indonesia sebagai anggota AIIB menjadi hal yang menarik untuk di kaji melihat bahwa Indonesia sebelumnya telah bergabung dengan beberapa lembaga keuangan internasional, baik yang berskela regional seperti ASEAN Development Bank, serta yang berskala Internasional seperti World Bank. (Khadijah dalam http://repository.umy.ac.id/bitstream) yang telah menjalin kerjasama dengan Indonesia dalam waktu yang cukup lama.

Indonesia menjadikan AIIB sebagai perpanjangan tangan dari kebutuhan Indonesia untuk mencapai kepentingan nasionalnya dalam meningkatkan kesejahteraan ekonomi. AIIB yang dibentuk khusus untuk memberikan pinjaman pembangunan infrastruktur di kawasan Asia akan memberikan keuntungan tersendiri bagi Indonesia, sebagai negara maritim terbesar di kawasan Asia Tenggara, akan menjadikan Indonesia sebagai partner yang diperhitungkan oleh AIIB. Indonesia kemudian setuju bergabung kedalam AIIB dan mengajukan sebagai salah satu negara pendiri, agar dana yang diperlukan untuk mencapai Poros Maritim Dunia 
dapat dicapai dari bantuan Tiongkok, share budget antar negara pendonor/investor lain, atau seutuhnya dibiayai dari kucuran dana AIIB.

Indonesia mengusung " $P M D$ " untuk menjadi garda terdepan kepentingan nasional Indonesia secara domestik dan internasional. Berdasarkan hal tersebut berbagai resiko dan peluang dari sektor maritim yang dikembangkan dengan tujuan penguatan dan pencapaian keamanan untuk membantu membentuk stabilitas dunia. Strategi ini ditempatkan pada domain maritim pada konteks permasalahan tersebut. Hal ini dibentuk dan dilakukan dengan pendekatan berdasarkan tujuan yang akan dicapai di masa yang akan datang. Pada akhirnya struktur pemerintahan yang akan menentukan efektifitas dan efisiensi penataan sektor maritim Indonesia. Permasalahan yang dihadapi secara mayoritas adalah ancaman terhadap sumber daya, berupa kriminalitas, terosisme hingga kejahatan kemanusiaan (Gandarsih, 2015). Sehingga membutuhkan regulasi yang kuat dan kebijakan internasional yang jelas serta kerja sama komprehensif secara global yang ditujukan pada keamanan bersama. Domain maritim sangat komplek dalam sistem internasional, dimana Indonesia perlu memainkan peran diplomasi dan penguatan kemampuan militer serta industri pertahanan.

TNI Angkatan Laut (TNI AL) Indonesia menempati posisi dan porsi yang strategis untuk mengupayakan optimalnya implementasi visi maritim dunia. Melakukan operasi dengan dukungan peralatan Alutsista yang canggih akan mempercepat pengawalan bagi pemerintah mencapai visi tersebut, memberikan gambaran bagi negara lain dan membangun pelaksanaan diplomasi (naval diplomacy) secara efektif. Pemerintah dan angkatan laut dapat melakukan beberapa upaya, diantaranya: modernization, build up, dan naval deployment. Dinamika yang berkembang juga perlu menjadi respon bagi Indonesia dalam menata pencapaian visi maritim dunia. Gejolak Laut China Selatan yang sampai sejauh ini belum menemukan suatu titik terang, menjadi lahan diplomasi maritim Indonesia secara berkelanjutan. Penyaiapan sumber daya strategis dan penguatan angkatan bersenjata merupakan bentuk kolaborasi efektif yang harus dikedepankan dalam kurun waktu sepuluh tahun kedepan.

\section{SIMPULAN}

Kebijakan Poros Maritim Dunia yang dicetuskan oleh Presiden Jokowi yang berada di tengah- tengah kebijakan Jalur Sutra Maritim China memiliki beberapa keuntungan dan ancaman. Berbagai keuntungan dan acaman tersebut membuat Indonesia berfikir keras untuk mewujudkan Poros Maritim Dunianya. Indonesia mengambil jalan untuk memanfaatkan tawaran Jalur Sutra Maritim dari China dengan bergabung dalam AIIB guna mewujudkan kebijakan Poros Maritim Dunianya.

Poros Maritim Dunia tentu memerlukan dana yang besar. Dana yang besar tersebut didapat dari beberapa investasi- investasi negara- negara asing salah satunya berasal dari China yang saat itu pula mencetuskan Jalur Sutra Maritimnya. Dampak tersebut berupa bantuan dalam bentuk pembangunan yang dapat menunjang Tol Laut. Akan tetapi perlu bagi Indonesia untuk melihat dampak negatifnya yaitu dalam sektor keamanan maritim. Keamanan maritim tersebut berupa ancaman wilayah 
Indonesia yang mungkin dapat disengketakan oleh China mengingat China merupakan negara yang sangat berambisi untuk menguasai wilayah Laut China Selatan. Maka Indonesia perlu menguatkan kekuatan TNI AL dalam mengawasi wilayah kedaulatan maritimnya.

Penguatan TNI AL di Indonesia sangat perlu dalam dalam menjaga stabilitas keamanan wilayah perbatasan Indonesia. TNI AL Indonesia menempati posisi dan porsi yang strategis untuk mengupayakan optimalnya implementasi visi maritim dunia. Melakukan operasi dengan dukungan peralatan Alutsista yang canggih akan mempercepat pengawalan bagi pemerintah mencapai visi tersebut, memberikan gambaran bagi negara lain dan membangun pelaksanaan diplomasi (naval diplomacy) secara efektif. Pemerintah dan angkatan laut dapat melakukan beberapa upaya, diantaranya: modernization, build up, dan naval deployment. Dinamika yang berkembang juga perlu menjadi respon bagi Indonesia dalam menata pencapaian visi maritim dunia.

Hal- hal di atas merupakan strategi yang dilakukan Indonesia dalam mewujudkan Poros Maritim Dunianya di tengah Kebijakan Jalur Sutra Maritim China. Tentu hal tersebut dilakukan guna untuk melihat stabilitas pembangunan infrastruktu dan menjaga stabilitas keamanan di Indonesia. Hingga saat ini belum ada pergerakan yang signifikan dalam strategi- strategi tersebut. Indonesia perlu bersiap dalam segala hal baik dalam internal maupun eksternal Indonesia.

\section{DAFTAR PUSTAKA}

Baylis, John. (2002). Strategy In The Contemporary World: An Introdution to Strategy Studies. Oxford.

https://www.bappenas.go.id/files/5115/0460/0330/Laporan_Prakarsa_Strategis_ Bidang_Kemaritiman_dan_SDA.pdf

Indonesia Sebagai Poros Maritim Dunia dalam http://www.presidenri. go.id/maritim/indonesia-sebagai-poros-maritim-dunia.html.

Kartini, Indriyana. (2005). Kebijakan Jalur Sutra Baru Cina dan Implikasinya bagi Amerika Serikat. Jurnal Kajian Wilayah. Vol.6 No. 2.

Mahan, Alfred Thayer. (2004). The Influence of Sea Power Upon History. Formatted by Black Mask Online.

Prasetya, Ade. (2017). Menuju Indonesia Sebagai Poros Maritim Dunia. https://www.academia.edu/19668985/MENUJU_INDONESIA_SEBAGAI_ POROS_MARITIM_DUNIA. 
Setiawan, Wahyu. (2017). Diplomasi Jalur Sutra, Overheating Ekonomi dan Interdependensi Kompleks: Sebuah Observasi Internal Atas Sebuah Modernisasi Peradaban dalam http://www.academia.edu/12313219/ Diplomasi_Jalur_Sutra_Overheating_Ekonomi_dan_Interdependensi_Komp leks_Sebuah_Observasi_Internal_Atas_Sebuah_Modernisasi_Peradaban diakses pada tanggal 30 Agustus

Suropati, Untung. (2016). Mengarungi Samudra Bersama Sang Naga "Sinergi Poros Maritim Dunia dan Jalur Sutra Maritim Abad ke-21. Pt. Elex Media Komputindo. Jakarta.

Taniputera, Ivan. (2007). History Of China. Ar-Ruzz Media. Yogyakarta.

Till, Geoffrey. (2004). Sea Power. Frank Cass. London.

Thamrin. Tantri S. R. (2017). Kedaulatan Laut dan Konsep Poros Maritim dalam http://www.academia.edu/11917693/KEDAULATAN_LAUT_DAN_KON SEP_POROS_MARITIM. 